\title{
Real Estate Taxes in Albania
}

\author{
Luciana Koprencka* ${ }^{1}$ Phd, Edmira Cakrani ${ }^{1}$ Phd(c), Migena Petani ${ }^{1}$
}

\begin{abstract}
:
The construction sector is one of the main sectors of the Albanian economy, which, during the last 20 years, has experienced the greatest economic growth. In 1991 this sector has contributed by $2.5 \%$ to the GDP, in 2006 by $4.9 \%$, while in 2008 , this sector has contributed by $14.9 \%$ to the national GDP. The relevant legislation has played an important role in the development of this sector. The applied laws have tried to maintain at low levels the real estate prices and to transform such a problematic sector, with reference to fiscal evasion and informality, into an easily controllable sector. The taxes applied in the construction sector are the same as in other economic sectors, although the taxation management in the construction sector, except for those common principles that regulate the tax management in general, is based on some specific rules related to the characteristics of this sector. Increase the level of taxation on the transfer of ownership to the extent of $10 \%$, paralyzed the housing market by reducing the number of sales, especially of real estate old, previously this was $0.3-5 \%$ of sales value.
\end{abstract}

JEL Classification: H21

Keywords: Construction sector, Value Added Tax, Profit tax, Real Estate Transfer Tax, Construction Cost, Real Estate Registration

\section{Introduction}

The inventory and structure of real estates owned by Albanians during the last 20-25 last years has undergone great and essential changes. During the socialist period, most of the Albanians were poor and owned no financial assets. Afterwards, the housing market was privatized by $90 \%(\mathrm{OECD})$. The housing situation in Albania left much to be desired with only 219 housings per 1000 people owned in the early 90 -ies, while in 2007 reached 260 much less than other ex-communist countries in Bulgaria, this number is 491 (Aman). That is why the construction sector nowadays is one of the most important markets in the local and national economy, requiring for a continuous intervention of the state. For this reason, laws concerning real estates and construction sector, during the last 20 years, have been frequently modified. The construction companies generate an average circulation of over 1.5 billion Euros per year. However, part of the

${ }^{1}$ University of Vlora "Ismail Qemali"

*Corresponding Author 
construction sector in Albania has developed in an informal way. Today, nearly 270.000 informal constructions can be counted as an investment of overall value 3 billion $\$$.

This work intends to study and present a view of the development process and problems related to the construction sector legislation in Albania, by asking the following preliminary questions: How has the construction sector evolved in Albania? Which are the policies pursued in the construction sector? What problems is the application of the relevant legislation in the construction sector encountering?

\section{The construction sector and its place in the Albanian economy}

The construction sector is one of the most developed sectors during the transitional period of the Albanian economy as this sector provides the greatest part of the Gross Domestic Product (GDP) in Albania. The construction sector has been characterized by a fast growth. Since some years the annual growth of this sector has varied from 10 to $15 \%$, listing this sector on the first place among other sectors of economy, which, on their part, have had a moderated growth. This growth would have been higher if this sector shouldn't have to face the obstacles created by either the central or the local government, such as fiscal costs and prices fixing, real estate transfer tax increase and construction permissions denial, which has caused a low use of the available capacities.

Figure 1. The contribution of the construction sector in the GDP

\section{The contribution of the construction sector in the GDP (\%)}

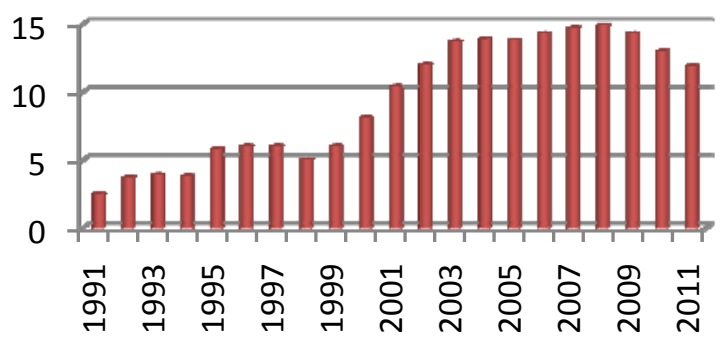

The contribution of the construction sector in the GDP (\%)

Source: Bank of Albania 
As shown in the figure 1 , in 1991 this sector contributed only $2.5 \%$ to the country's GDP; in 2000 it contributed about $8 \%$, while in 2008 this sector contributed $14.9 \%$ to the country's GDP. The GDP provided by the construction sector is more than twice higher than that provided by the industry and transport sectors, approaching the GDP provided by the agricultural sector. If we should add to these data the value of those economical contributions that represent citizens' independent investments (who construct or reconstruct their own houses) and the value of the intermediary services, the role and weight of the real estate sector in the Albanian economy would be greater. Since 2009, the construction sector has been involved from the crisis and contribution to GDP has declined to $11.9 \%$ in 2011.

The construction companies are organizations that carry out an important economical activity by circulating a volume of 1.5 billion Euro per year (or 190 billion Albanian Lek per year). 3292 companies (or 28\% of all companies) operated in the construction sector in 2009, in 1995 in Albania 1457 construction company operating (Tsenkova). There are 53.000 employees (or $32.1 \%$ of all employees) working in the construction sector (INSTAT). The construction companies contribute billions of Albanian Lek to the annual state budget as taxes and duties. According to the statistic data, since 1994, time when private constructions started to develop in Albania, a 15.7 million $\mathrm{M}^{2}$ surface of houses and apartments of value 400 billion Albanian Lek has been constructed in Albania. In other words, in 15 years 150-200 thousand buildings have been constructed, increasing the national estates stock market by more than one third. If we were to add here even a number of 240 thousand non-legally constructed but under legalization buildings, this would mean that averagely 800 billion construction investments have been made throughout this period.

\section{Value Added Tax (VAT) in the construction sector}

The laws applied in the Albanian construction sector have tried to transform such a problematic sector, with reference to fiscal evasion and informality, into an easily controllable sector, although we may say that application of such laws have not had a very positive influence on the real estate market.

One important law influencing a great deal on the real estate market is Law no. 7928 of 27 April 1995 "on value added tax". By virtue of this law, the value added tax should be applied to any taxable goods and services supply and to any goods import in Albania. The law excluded from the normal VAT scheme any land and buildings supply, and it applied only to the construction phase up to the cost level of real estates. This meant that VAT did not apply to the value of the 
construction on sale and the reason for that were the buildings prices kept at relatively low levels.

In 2006 there has been a strong debate on the VAT application to the building sales and a great part of specialists and constructors opposed to such application for the eventual negative effects it might bring on the fast increase of real estate price. As a consequence the VAT was not applied to the building sales.

At the moment when the real estate market in Albania is still unstable and there is the possibility of speculation with the prices, the effect of real estate price increase due to the application of VAT will be mostly felt by the customers. To be emphasized is the fact that the Albanian purchasing power cannot afford a fast increase in the real estate prices. The construction sector as one of the main sectors of the Albanian economy is the greatest tax payer, hence bearing the greatest fiscal burden. It's worth mentioning that in 2008 the construction companies paid the $31.4 \%$ of total budget Value Added Tax and the $29 \%$ of total budget Profit Tax. In 2011 Value Added Tax of the construction sector had a decrease of $31 \%$ compared to 2010 .

Figure 2. Revenues Generated by the Construction Sector(\%)

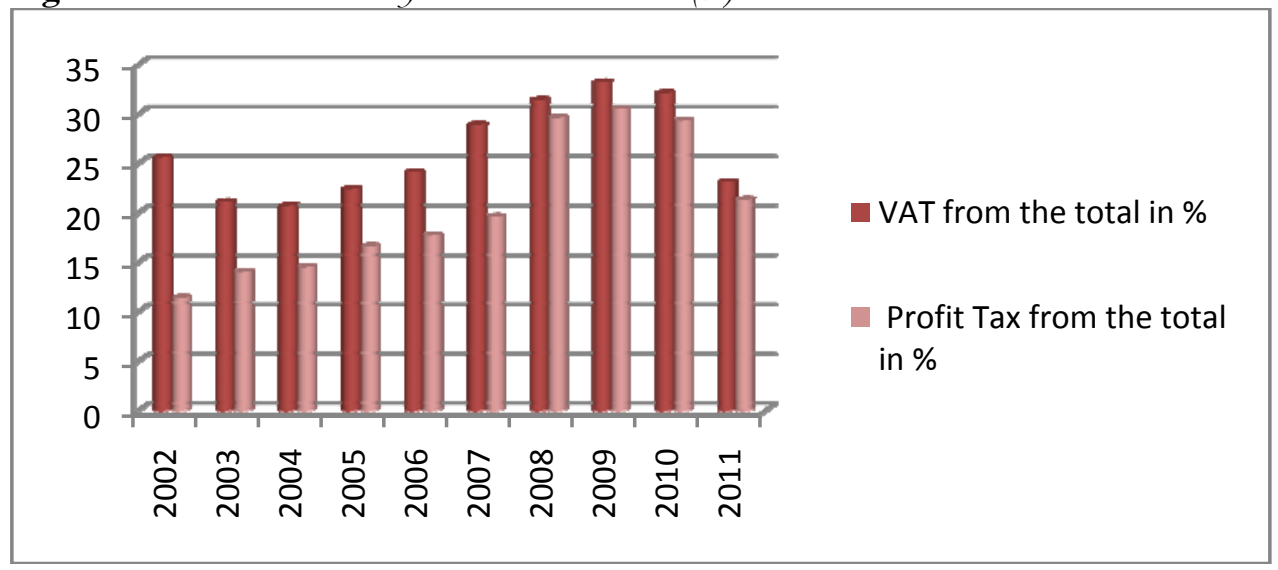

Source: INSTAT

\section{Real Estate Transfer Tax}

Another important law influencing on the real estate market is Law no. 8438 "on income tax". Until 2008 the real estate transfer tax was from 0.5 to 3\% of the total real estate sale price. In 2008 this law underwent some modifications, while a Directive n. 9 of 26 February 2008 "on real estate transfer tax" was emitted to establish that the real estate transfer should be taxed with $10 \%$ of generated capital profits. 
The tax is paid by the person transferring the real estate ownership title and the real estate is not registered unless such payment is confirmed by the real estate registration office. In fact such modification concerns only to individuals dealing with real estates. The establishment of such tax along with the setting of approved fiscal sale prices has somewhat paralyzed the real estate market concerning buildings constructed before 1990. This is due to the fact that difference between the price of such buildings at the time when they were bought by their present owners and the fiscal prices approved by the state is very high. The situation has caused an increase in the price of buildings constructed before 1990 as their owners include in the sale price even the real estate transfer tax, while it has favored the owners of new buildings, who are excluded from such law, because the difference between the purchasing price and the sale price is very low. The increase in the real estate price tends to increase inflation and decrease the number of transacting parties.

Table 1. Operations performed by Real Estate Registration Office (case numbers)

\begin{tabular}{|l|l|l|l|l|l|}
\hline Operations performed & 2005 & 2006 & 2007 & 2008 & 2009 \\
\hline Certificates of Ownership issued & 165,666 & 167,201 & 183,095 & 134,537 & 132,361 \\
\hline Petition for real estate registration & 17,664 & 20,780 & 26,314 & 18,678 & 20,173 \\
\hline $\begin{array}{l}\text { Petition for real estate registration, } \\
\text { division, merging }\end{array}$ & 18,016 & 17,018 & 17,301 & 14,747 & 15,857 \\
\hline Petition for ownership transfer & 44,149 & 38,341 & 48,236 & 25,128 & 24,830 \\
\hline Petition for registration & 1,790 & 1,910 & 1,491 & 1,248 & 624 \\
\hline Total & 247,285 & 245,250 & 276,437 & 194,338 & 157,815 \\
\hline
\end{tabular}

Source: Real Estate Registration Office

As shown in table 1, the number of operations performed at Real Estate Registration Office in 2008 has declined by $29.6 \%$ compared to the number of operations performed in 2007, while in 2009, this number, compared to the previous year, has declined by $23 \%$. Furthermore, we may note that there is a drastic decline by $51 \%$ in the number of transactions: in 2008 there are 25.128 transactions made compared to 48.236 transactions made in 2007 and the trend has continued in 2009 with only 24.836 transactions made. However, such an increase in the real estate transfer tax produces some positive effects in that it increases the state budget revenues, empowers formality (by adding another economic operation to the formal economy) and maybe it slows down the pace of the real estate bubble in Albania. 
Table 2 Revenues generated by real estate transfer tax(000 lek)

\begin{tabular}{|c|c|}
\hline Year & Revenues generated by real estate transfer tax \\
\hline $\mathbf{2 0 0 6}$ & 206.516 .257 \\
\hline $\mathbf{2 0 0 7}$ & 484.880 .251 \\
\hline $\mathbf{2 0 0 8}$ & 2.329 .209 .403 \\
\hline $\mathbf{2 0 0 9}$ & 2.181 .518 .272 \\
\hline $\mathbf{2 0 1 0}$ & 2.282 .051 .321 \\
\hline
\end{tabular}

Source: Real Estate Registration Office

According to the data provide(table 2), in 2009 it can be noted a slight decline of $6.4 \%$ in the revenues generated by the tax compared to 2008 . Such decline can be explained by the decline in the number of transactions, and in particular by the decline in the number of real estate transfer operations performed during 2009. Furthermore, there is also a decline in small and undeveloped cities, in my opinion due to the fact that this tax affects people of low economic status, who maybe are still waiting for this tax to decrease. Such an increase may result from the sale of small surfaced apartments constructed before 1990 to foreign or local investors, who use them as holiday apartments, while the price of newly built apartments of same surface is much higher.

The revenues generated from the real estate transfer tax in 2010 have increased by 4.6 compared to the revenues in 2009 , as it is expected an increase in the number of real estate transaction to be made during 2010.

\section{Decree on Approval of Construction Minimum Cost}

The Council of Ministers' Decree no. 173 of 29 March 2006 to the approval of construction minimum cost and to the establishment of house sale prices, defines the minimum fiscal cost per meter square, and on the basis of this cost it is calculated the tax payable by the construction companies. Previously the cost of new construction, was determined by market forces, in 2004 in Albania was $210 \$ / \mathrm{M}^{2}$ and , $150 \$ / \mathrm{M}^{2}$ in 1994 (Tsenkova) much lower than other countries in the east.Furthermore, another decree no. 514 of 15 August 2007 "on informatizing cost calculation and writing technical manuals for construction workings prices", defines that the application and supervision of any construction working shall be made according to the construction prices manual. It also defines that any duty to the state, with reference to the construction activity, shall be calculated on the basis of a technical analysis to the prices included in the construction prices manual.

Every year, the fiscal minimum costs and the sale fiscal minimum prices are approved in virtue of the above decrees. However the construction sector 
developers have strongly opposed to such decrees, considering them as a step back to the centralized and planed economy, where prices, material expenditure norms, output, number of employees and technology of construction are fixed and supervised. In the market economy it is absurd to write an obligatory projection manual to be applied, for the following reasons:

First, there is variable range of prices, which depends on many factors such as competition, clientele, exclusivity, demanded quantity, offered quality and payment method. There are various material expenditure norms, which depends on many factors such as, diversity in the market, technology, degree of working process mechanisms and quality of materials.

Second, the number of employees and their output varies in different companies, because businesses tend to reduce the number of employees by automating the working processes to the increases of the output.

Third, the technology of construction has undergone an unimaginable evolution and it perfections every day due to great competition.

The establishment of fixed prices to calculate construction cost bears the risk that the tax office may calculate duties incorrectly and abusively either to companies that present in the market a lower price than the fixed price included in the manual, or to companies that construct by a higher cost than the fixed price. Therefore, a certain situation is created where the state does not benefit from companies that construct by a higher cost for the reason that the calculation is made by the minimum fiscal cost and not by the actual cost. Furthermore, companies that construct by a lower cost than the fixed price included in the manual will have higher duties.

But, in our country, many companies are not yet aware of declaring and paying their taxes, therefore they compete unfairly with regular companies. However, the establishment of fixed and supervised prices is not a good solution. On the other hand, the solution shall not be a short-term but a long-term one. In my opinion a temporary good solution might be the setting of some other directing minimum fiscal parameters, below which, no company or individual should be allowed to go down. In this way it is for certain that fraudulent companies or individuals shall have no possibility of cheating and the market will be characterized by a fair competition.

The existence of so many referring taxes from the raw materials to the final price seems to have either a psychological or a substantial effect in the real estate prices in Albania. Therefore, although there is a low demand on real estates, the prices of such estates are not undergoing any decrease. The increase from year to year of the construction average cost and of the fiscal minimum price to be declared by the constructors for the apartments they have already sold will result in an increase of the apartments' price. 


\section{Results and Discussion}

The work makes an analysis to the construction sector performance and the problems generated by the legal reform to this sector. One of the main contributions in this work is the synthetized information on the way the economic development has been associated with a rapid development in the construction sector. We can modestly confirm that the analysis made to the influence of the fiscal system on the real estate market and construction sector, brings valuable results to be applied in the construction sector and real estate market. The construction sector and the real estate market is a very complex market influenced by many factors, some of which very hard to be measured, particularly those related to the taxing management.

The analysis of the role of different factors is more complicated than the temporary tendencies during the period available to the explanatory variables. This creates an important identification problem impeding the accurate evaluation of long-term consequences in the construction sector. Data available in Albania are for short-term periods; therefore it is hard to find more detailed data. The real estate market is a decentralized market and it creates a great potential for information asymmetry.

- The accuracy of available data is also problematic. Part of the data, although received by official resources, is still contradictory.

- $\quad$ Furthermore, parts of the variables are not stable and vary from year to year. This increases unpredictability, while often such variables are subject to political or clientelistic decisions.

- This study contains data on urban areas, as in rural areas such data are almost inexistent.

Therefore, although the construction sector and the real estate market in Albania are very important, the data are limited. For example, there is no answer for this simple question: What is the number of houses in Albania? There are a relatively small number of studies related to the real estates in Albania. Financial researches in the field of real estate market in our country are not so many for the following reasons, the difficulties encountered by this market in comparison with the financial markets and the access to the data associated with this market.

\section{Conclusions and recommendations}

1.The construction sector is the main sector of the Albanian economy. The contribution of this sector to the Gross Domestic Product (GDP) has increased from year to year by $2.5 \%$ in 1991 to reach the highest level by $14 \%$ after 2006 . 
2.In 2007, for the first time some declines were observed in the construction sector after many positive years. The investments reached the lowest levels, almost equal to those of 2001. This was a reaction of the construction sector to the world's financial crisis that has started in the construction sector of the USA. 3.In the construction sector, the law excludes from the normal VAT scheme any land and buildings supply, and VAT applies only to the construction phase up to the cost level of real estates. This means that the buildings' value on sale is not charged with VAT and the buildings prices are kept at relatively low levels.

4.In 2008 the real estate transfer tax underwent an increase from $0.5-3 \%$ of the total real estate sale value to $10 \%$ of capital profits generated by real estate sales. This resulted in an increase in revenues generated by real estate transfer tax.

5.A decree made in 2006 to the approval of construction minimum cost, to the informatization of cost calculation and writing of technical manuals for construction workings prices is a step back to a centralized and planed economy. 6.In the market economy it is absurd to write an obligatory projection manual to be applied for the reason that there is a variable range of prices, the number of employees and their output varies in different companies, and the technology of construction has undergone an unimaginable evolution and it perfections every day due to great competition.

\section{References}

Amann, W. (2005) How to boost rental housing construction in CEE-/SEE-Countries, The Housing Finance International Journal, IUHE, pp 3-5 ,12/2005.

Besnik, A, 1998: Housing Rehabilitation and Urban Renewal Strategies: NGOs/CBOs and Housing for Low-Income people in Tirana. In: Cernic Mali, B. - Dimitrovska-Andrews, $\mathrm{K}$ - Turner, B (eds): Housing in Transition. Ljubljana, Urban Planning Institute of the Republic of Slovenia, pp 87-99

Buckley, R. and Tsenkova, S. (2001). Housing Market Systems in Reforming Socialist Economies: Comparative Indicators of Performance and Policy. European Housing Policy vol. 2: pp 3-34

Bertaud, A. and Renaud, B (1997). Socialist cities without land markets, Journal of Urban Economics. 41(1), 37-51.

Case K E, Quigley J M (2008) How Housing Booms Unwind: Income Effects, Wealth Effects, and Feedbacks through Financial Markets. European Journal of Housing Policy 8(2),pp 161-180.

Harloe, M. and Martens M (1983) Comparative housing research. Journal of Social Policy (13), pp 255-277.

Hegedüs, J - Mayo, Stephen E. - Tosics, I. 1996: Transition of the Housing Sector in the East Central European Countries In: Rewiew of Urban \& Regional Development Studies 8. 1996. pp. 101-136

Hegedüs J. and I. Tosics (1992). Past Tendencies and Recent Problems of the East European Housing Model, in Turner, B.; J. Hegedüs; I. Tosics (eds.) The Reform of Housing in Eastern Europe and the Soviet Union. London: Routledge. 
Hegedüs, J. and Tosics, I. (2001): Housing Problems in South Eastern Europe, COE,SEER,Strategic_review/Publications/Housing_Network/EHousingProblemsSE ER(4-5 december 2001)1.asp SOUTH EAST EUROPE STRATEGIC REVIEW ON SOCIAL COHESION HOUSING NETWORK

Hegedüs, J. and Varhegyi, E(1999), The crisis in housing financing in Hungary in the 1990s, Urban Studies, Vol. 37, No. 9, pp. 1619-1641

Kornai, J. (1992), The socialist system, the political economy of communism, Princeton University Press ISBN: 9780691003931

Moores Margaret, E. Flynn Norman D. (1997), Real Estate Professionals and the Immovable Property Market in Albania, working paper, Albanian Series No 11, Land Tenure Centre, University of Wisconsin - Madison, September 1997, pp 5-7

MNB (2004a), "Household foreign currency borrowing in Hungary and in the new member states of Central and Eastern Europe", Report on Financial Stability, Hungarian National Bank, pp. 88-90

Musil, J (1993) Changing Urban Systems in Post-communist Societies in Central Europe: Analysis and Prediction. Urban Studies 30(6), pp 899-905.

Renaud, M. B. (1996), "Housing finance in transition economies", The World Bank, Policy Research Working Paper, No. 1565, pp 10-17

Petrovic, M. Post-Socialist Housing Policy Transformation in Yugoslavia and Belgrade, European Journal of Housing Policy 1(2), 2001, pp 211-231

Svejnar, J (2002) Transition economies: Performance and challenges. The Journal of Economic Perspectives 16(1), pp 3-28.

Tsenkova, S, (2004) Housing policy reforms in Post Socialist Europe,ISBN 978-3-7908-2114-7 pp 171-175

Tsenkova, S, (2000) Trends and Progress in Housing Reforms in South Eastern Europe. Paris: Council of Europe Development Bank This publication is available free of charge from: Council of Europe Development Bank, pp 16,48-53

Council of Europe Development Bank (2003) Housing in South Eastern Europe. Solving a Puzzle of Challenges. Paris: Council of Europe Development Bank.pg 13-15. An Initial Assessment of the Albanian Housing Sector. The Urban Institute: Prepared for the Office of Housing and Urban Programs (USAID 1993).

Economic Commission for Europe, Geneva: Country Profiles on the Housing Sector, Albania, 2000, pp 15-27, pp 45-50

European Commission for Europe(2005), Housing and the business cycle, Quarterly Report on the Euro Area, Vol. 4, No. 2, pp. 30-40

ECB, European Central Bank (2003), Structural factors in the EU housing markets, pp. 35-48.

INSTAT (2004a), Migration in Albania. Population and Housing Census 2001, Tirana.

OECD (2002): Housing Finance in Transition Economies. Paris: OECD.www.oecd.org

OECD (2005) Housing Finance Markets in Transition Economies. Trends and Challenges, ISBN: 9789264010178, pp 34-40, Paris, OECD

SEED (2002), Building construction sector study and pipeline development. Albania, South Europe Enterprise Development (SEED), International Finance Corporation (IFC), The World Bank Group, Sarajevo, February 2002.

www.bankofalbania.org

www.instat.gov.al

www.minfin.gov.al

www.zrpp.gov.al

www.aluizni.gov.al 